\title{
Risk Management Model And Acces To Business Financing
}

\author{
Mursalim Nohong ${ }^{1}$, Muhammad Sobarsyah ${ }^{2}$, Wardhani Hakim ${ }^{3}$, and Abdul Razak Munir ${ }^{4}$ \\ \{mursalimnohong@fe.unhas.ac.id ${ }^{1}$ \} \\ 1,2,3,4 Department of management, Faculty of Business and Economics, Hasanuddin University, Indonesia
}

\begin{abstract}
The aims of this study are to find out the effect of Government policy, Marketing, Production, risk management and macro environment variables on Access to business financing. The sample in this study is broiler breeders who have never obtained credit from formal financial institutions as many as 60 people which thirty farmers in Sidenreng Rappang Regency and thirty farmers in Pinrang Regency. Data then analyzed with Multiple Regression Analysis. The results show that Government policy, Marketing, Production, risk management, and macro environment have a positive and significant effect on Access to Business Financing.
\end{abstract}

Keywords: risk management, business financing, small medium enterprises.

\section{Introduction}

Laying chicken has several advantages over other protein sources because they can improve the quality of human resources from animal protein contained and have an impact on income and absorption of community employment. Poultry production makes the biggest contribution to animal protein for the human body. In terms of production, as reported by FAO, poultry meat dominates around $33 \%$ of global meat production. In addition, the production process of the laying chicken sector is environmentally friendly and has the potential to fulfil human needs for animal feed supplies.

Animal protein is superior to plant protein because of its high content of amino acids and that the supply of protein in adequate quantity is a vital factor in the life of a man (Iheke, 2016). The livestock sector is one of the main sectors to sustain industrial growth. Until now the livestock sector has become one of the engines of economic and regional and national development. Sidenreng Rappang and Pinrang Regencies are not only South Sulawesi's food granaries, but these two regions are price controllers in Eastern Indonesia. Contributions provided by sectors that are not excluded from good business management performance. Optimization of internal and external resources to develop strategies that are appropriate to the environment and business performance. Meeting the need for working capital and investment is one of the main sectors of the sector. Rapid environmental changes to the level of quality associated. Therefore, the greater the risk posed by the environment, the greater the usefulness. The changing in the exchange rate of the rupiah against the dollar in effect on prices, changes in credit interest rates, high inflation, competition, diseases are forms of risk that must be managed properly by each business actor.

Agricultural production decisions include livestock are taken in the environment of risk which affects the production and marketing decisions of the farmer. Farmers make a decision every now and then that affect farming operations. Production decisions are generally made under the environment of risks and uncertainties as yield, product prices, input prices, and 
quantities are usually not known with certainty when investment decisions are being made. Many of the factors that affect the decision cannot be predicted with complete accuracy (Ayinde et.al., 2008). Factors such as climate, input prices, technological changes, theft, pollution, pests and diseases, business management costs, government policy stability, fluctuations in loan interest rates, labor supply, and farmers' economic factors. All of these changes are examples of the risks and uncertainties that farmers face in managing their farms as a business (Adepoju et.al, 2013). These factors make small-scale farmers inadequately equipped against risks and uncertainties (Ayinde et al., 2008).

There are different types of risk an organization may face, including market risks, credit risks, health and safety risks, environmental risks, fire risks, bomb threats, computer risks, theft and fraud, industrial espionage, technical risks, kidnap and ransom, extortion, accidental and criminal risks and many more (Meulbroek, 2002). Based on the description, an organizational risk is classified as the internal risk that can be controlled and external risks are relatively difficult to control.

The farming enterprise's risks are risks that are likely to occur in the form of injury, damage, and uncertainty about the agricultural products that will be obtained. Such risk farming is closely related to variables that cannot be predicted perfectly including biological, climate and price variables (Government of India, 2006). They could be grouped in agribusiness enterprises into a social, market, institutional, financial, production and foreign exchange risk (Asogwa et al., 2014).

Risks associated with the farmers are categorized into (i) market risks (demand and supply) conditions, (ii) risk related to inflation and interest rates and (iii) production risk (Olarinde et.al, 2010). Risk management in poultry farming is extremely important because failure to manage farming risks has direct negative effects on farmers' income, market stability, and potential food security. Risk management in practice uses valuation techniques to determine the level of risk faced by the company and develops a strategy-setting process to control risks to acceptable levels. (Abotsi et.al, 2014). Therefore the process of understanding, identifying, and defining risks based on the probability of occurrences and impacts caused is the first step in developing an effective risk management strategy (Hillman, 2010).

The low ability of Poultry SMEs in obtaining credit as a source of working capital and investment activities funding also has the potential to be a risk faced. One of the major problems confronting small and medium scale farmers including poultry farmers is poor access to adequate credit (Adeyonu et.al, 2017). However, the ability to access appropriate capital sources is a problem that must be resolved by the poultry farmer to produce the bulk of domestic agricultural output (Eze \& Ibakwe, 2007).

In general, financial institutions that play a role in providing credit to farmers assume that these farmers are not eligible for a credit. The reason is that farmers have low savings or no business guarantees. But for farmers, the factor of failure in managing credit is because the distribution is not on time, high-interest rates and complicated requirements (Adegbite et.al, 2008).

This study analyses the risk management model and its relation to the ability to access funding sources for livestock sector business actors.

\section{Method}

To achieve the objectives of this study, laying chicken are used by farmers who have never obtained credit from financial institutions as an analysis unit of 60 respondents, where the amount is greater than the minimum sample. The respondent also manages risk in developing 
his business. 30 (thirty) farmers in Sidenreng Rappang Regency and 30 farmers in Pinrang Regency.

Sampling was done by Snowball sampling technique which found that some of the respondent farmers in two sub-district locations who had never obtained capital/credit from formal financial institutions and based on recommendations or information from the initial breeders were tracked by other farmers so that the number of breeders reached 60 farmers. Data collection is done by using a questionnaire where each answer given by the respondent represents.

The measurement of each variable is provided in table 1. below:

Table 1. Operational variable and measurement

\begin{tabular}{|c|c|c|c|}
\hline Variable & Definition & Indicator & $\begin{array}{c}\text { Measurement } \\
\text { scale }\end{array}$ \\
\hline $\begin{array}{l}\text { Government policy } \\
\left(\mathrm{X}_{1}\right)\end{array}$ & $\begin{array}{l}\text { Respondent's } \\
\text { perception of the } \\
\text { policy taken by the } \\
\text { government }\end{array}$ & $\begin{array}{l}\text { active government roles, } \\
\text { management supervision } \\
\text { assistance, Government } \\
\text { assistance in providing } \\
\text { opportunities for business } \\
\text { credit assistance, availability } \\
\text { of business development } \\
\text { programs, assistance in } \\
\text { accessing business loans. }\end{array}$ & Ordinal \\
\hline $\operatorname{Marketing}\left(\mathrm{X}_{2}\right)$ & $\begin{array}{l}\text { Respondent's } \\
\text { perception of the } \\
\text { marketing effort }\end{array}$ & $\begin{array}{l}\text { production capability, } \\
\text { selling price, and market } \\
\text { location. }\end{array}$ & Ordinal \\
\hline Production $\left(\mathrm{X}_{3}\right)$ & $\begin{array}{l}\text { Respondent's } \\
\text { perception of the } \\
\text { production process }\end{array}$ & $\begin{array}{l}\text { product quality, feed } \\
\text { availability, feed prices, ease } \\
\text { of obtaining feed. }\end{array}$ & \\
\hline management & $\begin{array}{l}\text { Respondent's } \\
\text { perception of risk } \\
\text { management }\end{array}$ & $\begin{array}{l}\text { a series of processes carried } \\
\text { out by respondents in } \\
\text { identifying, monitoring and } \\
\text { managing potential risks in } \\
\text { order to minimize the } \\
\text { negative impact they may } \\
\text { have on an organization. }\end{array}$ & Ordinal \\
\hline $\begin{array}{l}\text { Macro environment } \\
\left(\mathrm{X}_{5}\right)\end{array}$ & $\begin{array}{l}\text { Respondent's } \\
\text { perception of the } \\
\text { macro environment }\end{array}$ & $\begin{array}{l}\text { Factor price stability, } \\
\text { changes in loan interest } \\
\text { rates, exchange rate stability. }\end{array}$ & Ordinal \\
\hline
\end{tabular}

\section{Results And Discussion}

\subsection{Testing Regression Assumptions}

\subsubsection{Normality test}

The normality test with the points on the pp-plot graph shows the spread pattern following a straight line and the histogram graph shows the curves that form a normal 
distribution so that the normality assumption is fulfilled. The normality test was carried out using the Kolmogorov Smirnov test with a significance value $>0.05$. The test results obtained a Kolmogorov Smirnov significance value of 0.092. based on this value, it is concluded that the assumption of normality meets.

\subsubsection{Multicollinearity test}

The assumption of multicollinearity is calculated by the value of VIF (Variance Inflating Factor) where if the VIF value is $<10$, there is no autocorrelation. Multicollinearity test results as in the following table:

Table 2. Non-Multicollinearity assumption test results

\begin{tabular}{ccc}
\hline Independent variable & VIF & remarks \\
\hline $\mathrm{X}_{1}$ & 1.173 & non-multicollinearity \\
\hline $\mathrm{X}_{2}$ & 1.285 & non-multicollinearity \\
\hline $\mathrm{X}_{3}$ & 1.337 & non-multicollinearity \\
\hline $\mathrm{X}_{4}$ & 1.188 & non-multicollinearity \\
\hline $\mathrm{X}_{5}$ & 1.326 & non-multicollinearity \\
\hline
\end{tabular}

Table 2 shows that the five research variables have VIF values below 10 which means that multicollinearity is not found for these variables so that they are appropriate to be used as independent variables in the model.

\subsubsection{Heteroscedasticity test}

Heteroscedasticity is tested using the Gletjer test, which is regression between absolute residuals and independent variables. If the value of $\mathrm{Sig}$ (probability) $>0.05$, indicates no heteroscedasticity, otherwise if the value of $\mathrm{Sig}<0.05$, indicates the occurrence of heteroscedasticity.

Table 3. Heteroscedacity test results

\begin{tabular}{ccc}
\hline Dependent variable & Significance & remarks \\
\hline $\mathrm{X}_{1}$ & 0.680 & non-heteroscedasticity \\
\hline $\mathrm{X}_{2}$ & 0.223 & non-heteroscedasticity \\
\hline $\mathrm{X}_{3}$ & 0.204 & non-heteroscedasticity \\
\hline $\mathrm{X}_{4}$ & 0.062 & non-heteroscedasticity \\
\hline $\mathrm{X}_{5}$ & 0.857 & non-heteroscedasticity \\
\hline
\end{tabular}

Table 3 shows that the variables tested did not contain heteroscedasticity, because of all values of Sig $>0.05$. This shows that the addition of the amount of data does not cause a correlation between the amount of data and residuals.

\subsubsection{Linearity test}

The assumption of linearity using the Curve Fit method. Linearity testing is carried out by referring to the parsimony principle, which is when all models used as a basis for testing are significant or not significant means that the model is said to be linear. Model specifications used as the basis for testing are linear, quadratic, cubic, inverse, logarithmic, power, 
compound, growth, and exponential models. The results show that the linear model shows significant results so that the linearity assumptions are met.

\subsubsection{Model test}

The test results obtained the determination coefficient value of R Square of 0.650 or $65.0 \%$. This means that financing access variable is affected by $65.0 \%$ by government policy $\left(\mathrm{X}_{1}\right)$, marketing $\left(\mathrm{X}_{2}\right)$, production $\left(\mathrm{X}_{3}\right)$, risk management $\left(\mathrm{X}_{4}\right)$, and macro environment $\left(\mathrm{X}_{5}\right)$ while the remaining $35.0 \%$ is influenced by other variables outside the two independent variables examined in this research.

Table 4: The result of multiple linear regression

\begin{tabular}{ccccc}
\hline variable & $\begin{array}{c}\text { Coefficie } \\
n t\end{array}$ & Beta & $\begin{array}{c}\text { T-value } \\
\text { (Sig.) }\end{array}$ & remarks \\
\hline constant & 1.166 & & $\begin{array}{c}0.430 \\
(0,668)\end{array}$ & \\
\hline$\left(\mathrm{X}_{1}\right)$ & 0.118 & 0.106 & $\begin{array}{c}1.374 \\
(0,174)\end{array}$ & $\begin{array}{l}\text { Non } \\
\text { significant }\end{array}$ \\
\hline$\left(\mathrm{X}_{2}\right)$ & 0.427 & 0.391 & $\begin{array}{c}4.850 \\
(0,000)\end{array}$ & significant \\
& & & 3.350 & significant \\
$\left(\mathrm{X}_{3}\right)$ & 0.195 & 0.276 & $(0,001)$ & \\
\hline$\left(\mathrm{X}_{4}\right)$ & 0.556 & 0.250 & $\begin{array}{c}3.217 \\
(0,002)\end{array}$ & significant \\
\hline$\left(\mathrm{X}_{5}\right)$ & 0.460 & 0.210 & $\begin{array}{c}2.564 \\
(0,013)\end{array}$ & significant \\
\hline $\mathrm{T}_{\text {tabel }}$ & $=1.995$ & & & \\
\hline $\mathrm{R}$ & $=0.650$ & & & \\
Square & & & & \\
\hline $\mathrm{F}_{\text {test }}$ & $=25.648$ & & & \\
\hline Sig F & $=0.000$ & & & \\
\hline $\mathrm{F}_{\text {table }}$ & $=2.348$ & & & \\
\hline
\end{tabular}

\subsection{Discussions}

\subsubsection{Risk management model}

Risk management is a process that involves techniques and methods for identifying, evaluating and analyzing risks. This process is represented by various activities such as, measuring, controlling, reporting or choosing decisions that aim to eliminate risk. each company aims at value maximization and risk minimization. Activities to identify risk factors, evaluation, control, and risk reduction are the main steps taken in risk analysis and depend on the period of time taken into account, costs, and benefits, an honesty of data and information, possible externalities and interdependencies between events.

Institutions are faced with many risks including such as market risk, which is the risk that the market value of an asset will decline resulting in capital losses when sold. Operating risk arises from the failure of internal controls in the business environment. Risks faced by financial institutions include market risk, credit risk, performance risk and operational risk which results from cost incurred from mistakes made in carrying out transactions such as 
settlements, failure to meet regulatory requirements and untimely collections (Tandelilin et al., 2007).

Table 5. Types and strategy handling risk

\begin{tabular}{ll}
\multicolumn{1}{c}{$\begin{array}{c}\text { Types and sources of } \\
\text { risk }\end{array}$} & \multicolumn{1}{c}{ The handling strategy } \\
\hline Predatory animals & Regular maintenance and monitoring of the cage area \\
\hline Virus & $\begin{array}{l}\text { 1. Biotic spraying } \\
\text { 2. Sanitary enclosure }\end{array}$ \\
\hline extreme climate or season & counseling and monitoring weather conditions for employees \\
\hline Sound pollution (noise) & 1. Make a warning pamphlet \\
& 2. Provides a music player to reduce noise \\
\hline Finance and capital & 1. Orientation on the use of funds sourced from retained \\
& 2. Reorings \\
\hline Employee & 1. Increased ability and skills in business management \\
& 2. Improving occupational health and safety \\
\hline Process and system & 1. Control systems used in operational activities at home \\
& 2. SOPs used in chicken farms \\
\hline Technology & 1. Reliability of the heating device used \\
& 2. Reliability of chicken drinking water pipe distribution system \\
3. Reliability of the fan \\
\hline Risk of death & 1. Maintain health \\
2. Knowing various kinds of chicken diseases \\
3. Choose superior seeds \\
\hline Price stability & 2. Monitoring the determinants of price changes \\
&
\end{tabular}

\subsubsection{Relationship between variables}

\subsubsection{Effect of government policy $\left(\mathrm{X}_{1}\right)$ on financing access $(\mathrm{Y})$}

The results of the analysis show the relationship coefficient between government policy $\left(\mathrm{X}_{1}\right)$ and access to finance $(\mathrm{Y})$ is 0.106 and a $\mathrm{p}$-value of 0.174 . $\mathrm{p}$-value $>0.05$. It means that government policy $\left(\mathrm{X}_{1}\right)$ is not significant to financing access $(\mathrm{Y})$. This means that the high and low value of government policy $\left(\mathrm{X}_{1}\right)$, cannot improve the ability to access financing for the livestock sector (Y) SMEs.

By paying attention to the indicator with the highest mean value shows that government policy through the provision of information, especially the price of products and factors of production, will help businesses to access formal financing sources. Other information needed is related to the availability and requirements for obtaining credit from a financing institution.

\subsubsection{Effect of marketing $\left(\mathrm{X}_{2}\right)$ on financing access $(\mathrm{Y})$}

The calculation results show the marketing coefficient of influence $\left(\mathrm{X}_{2}\right)$ with access to finance $(\mathrm{Y})$ is 0.391 with a p-value of 0.000 . P-value $<0.05$ indicates that marketing $(\mathrm{X} 2)$ has a significant effect on financing access (Y). Coefficient values with positive signs indicate unidirectional relationships. This means that the higher the marketing value $\left(\mathrm{X}_{2}\right)$, will affect the high value of financing access $(\mathrm{Y})$. 


\subsubsection{Effect of production $\left(\mathrm{X}_{3}\right)$ on financing access $(\mathrm{Y})$}

Based on the results of the analysis, the coefficient of influence between production $\left(\mathrm{X}_{3}\right)$ and access to finance $(\mathrm{Y})$ is 0.276 with a $\mathrm{p}$-value of 0.001 . a p-value $<0.05$ indicates that Production $\left(\mathrm{X}_{3}\right)$ is significant for financing access $(\mathrm{Y})$. coefficients with positive signs indicate unidirectional relationships. This means that the higher the production value $\left(\mathrm{X}_{3}\right)$, the higher the value of financing access $(\mathrm{Y})$.

\subsubsection{Effect of risk management $\left(\mathrm{X}_{4}\right)$ on financing access $(\mathrm{Y})$}

Based on the results of the analysis, the correlation coefficient between risk management $\left(\mathrm{X}_{4}\right)$ and access to finance $(\mathrm{Y})$ is 0.250 with a p-value of 0.002 . a p-value $<0.05$ indicates that risk management $\left(\mathrm{X}_{4}\right)$ is significant for financing access $(\mathrm{Y})$. coefficients with positive signs indicate unidirectional relationships. This means that the higher the ability of SMEs in risk management $\left(\mathrm{X}_{4}\right)$, the higher the value of financing access $(\mathrm{Y})$.

\subsubsection{Effect of the macro environment $\left(\mathrm{X}_{5}\right)$ on financing access $(\mathrm{Y})$}

Based on the results of the analysis, the relationship coefficient between the macro environment $\left(\mathrm{X}_{5}\right)$ and financing access $(\mathrm{Y})$ is 0.210 with a $\mathrm{p}$-value of 0.013 . a $\mathrm{p}$-value $<0.05$ indicates that the macro environment $\left(\mathrm{X}_{5}\right)$ is significant for financing access $(\mathrm{Y})$. coefficients with positive signs indicate unidirectional relationships. This means that the higher the macro environment value $\left(\mathrm{X}_{5}\right)$, the higher the value of financing access $(\mathrm{Y})$.

\section{Conclusions}

The livestock sector is one of the main sectors to sustain industrial growth. The sector has several virtues in terms of quality of life, economic, social aspects. From the aspect of quality of life, human beings are able to improve the quality of human resources through the provision of animal protein. From the economic and social aspects, it becomes a source of income and provides employment not only in rural areas but also in urban areas.

Risks that often found in the business development of the livestock sector are a). Predatory animals, b). A virus, c). Extreme climate or season, d). Sound pollution (noise), e). Finance and capital, g). The employee, h). Process and system, j). Technology, k). Risk of death, and 1). Price stability.

The increasing ability to access financing for the livestock sector is influenced by government policy, marketing, production, risk management, and macro environment.

\section{References}

[1] Abotsi, A. K., Dake, G. Y., \& Abankwa Agyepong, R. (2014). Factors Influencing Risk Management Decision of Small and medium Scale Enterprises in Ghana. Contemporary Economics. https://doi.org/10.5709/ce.1897-9254.153

[2] Adegbite, D. A., Olaoye, O. J., \& Oloruntoba, A. (2008). Performance Assessment of Ogun State Agricultural and Multi-Purpose Credit Agency (OSAMCA) in Credit Delivery and Operation (2004-2006), 3, 127-157.

[3] Adepoju, A. O., Timothy, O. A., \& Oyekale, A. S. (2013). Risk coping behaviour of small scale poultry farmers in Ogun State, Nigeria. Asian Journal of Animal and Veterinary Advances. https://doi.org/10.3923/ajava.2013.786.795

[4] Adetayo, A. K., Ademiluyi, I. O., \& Itebu, J. O. (2013). Challenges of Small Poultry 
Farms in Layer. Global Journal of Science Frontier Research Agriculture and Vetinary Sciences.

[5] Adeyonu, A., Ajiboye, B., Isitor, S., \& Faseyi, S. (2017). An analysis of the factors influencing access to credit by poultry farmers in Abuja, Nigeria. Agriculturae Conspectus Scientificus.

[6] Asogwa, B. C., Abu, O., \& Ogene, A. (2014). Agricultural Risk Management and Production Efficiency among Peasant Farmers in Benue State , Nigeria, 3(5), 373-391.

[7] Ayinde, O. E., Omotesho, O. A., \& Adewumi, M. O. (2008). Risk attitudes and management strategies of small - scale crop producer in Kwara State , Nigeria : A ranking approach. African Journal of Business Management.

[8] Eze, C. ., \& Ibakwe, U. . (2007). Determinants of loan repayment under the Indigenous Financial System in Southeast, Nigeria. “. The Social Sciences Medwell Journals 2007. Retrieved from http://docsdrive.com/pdfs/medwelljournals/sscience/2007/116-120.pdf

[9] Government of India. (2006). Report of the working group on Risk Management in Agriculture. Planning Commission, 1-144. Retrieved from http://scholar.google.com/scholar?hl=en\&btnG=Search\&q=intitle:the+working+group + on + risk + management + in + agriculture + for + the + eleventh + five + year + plan $+(2007-$ 2012)\#0

[10] Hillman, M. (2010). Supply Chain Risk Management: Literature Review and Future Agenda, 3100(8), 93-96.

[11] Iheke, O. R. (2016). Risks management in poultry production in ikeduru local government area of imo state , Nigeria Iheke and Igbelina 2016 risks management in poultry production in ikeduru local government area of imo state, nigeria, (january).

[12] Meulbroek, L. K. (2002). Integrated Risk Management for the Firm: A Senior Manager's Guide. SSRN. https://doi.org/10.2139/ssrn.301331

[13] Olarinde, L. O., Manyong, V. M., \& Akintola, J. O. (2010). Factors influencing risk aversion among maize farmers in the Northern Guinea Savanna of Nigeria: Implications for sustainable crop development programmes. Journal of Food, Agriculture and Environment.

[14] Tandelilin, E., Kaaro, H., Mahadwartha, P. A., \& Supriyatna. (2007). Corporate Governance, Risk Management, and Bank Performance: Does Type of Ownership Matter? Eadn Working Paper, No. 34. 